\title{
Epibionts and intermoult duration in the crab Bathynectes piperitus
}

\author{
Josep-Maria Gili, Pere Abelló, Roger Villanueva
}

Institut de Ciències del Mar (CSIC), Passeig Nacional s/n, E-08039 Barcelona, Spain

\begin{abstract}
Crustacean carapaces act as semipermanent hard substrata and can provide useful information on moulting and other biological characteristics of the host. The patterns of epibiosis on the portunid crab Bathynectes piperitus were studied from samples collected by trawling off southern Namibia between September 1987 and December 1988. Four species were identified as epibionts of this crab: the hydroid Stegopoma plicatile, the polychaete Spirorbis patagonicus, the pedunculate cirriped Poecilasma kaempferi and the bryozoan Nolella annectens. The patterns of distribution of the 4 epibionts were studied on the carapaces of 318 adult male crabs. The number of individuals or colonies of each epibiont species was noted within each of 4 carapace areas. The hydroid occurred preferentially on the anterior part $(46.9 \%)$ of the carapace, whereas the cirriped was found most commonly on the posterior $(45.7 \%)$. The polychaete was more common on the inferior parts $(53.1 \%)$ as was the bryozoan $(80.3 \%)$. The relationships between the size of the crab and the number of polyps (hydranths), the number of colonies and the number of gonothecae of $S$. plicatile were also analyzed, since these parameters could give an estimate of the intermoult period of the host. Based on the identification of 3 cohorts in both the hydroid and cirriped populations, and taking into account their probable age, a minimal time for the intermoult period can be defined. Recruitment and reproduction of the hydroid show that the process of colonization is continuous on all sizes of adult crab.
\end{abstract}

\section{INTRODUCTION}

Most sessile marine animals are highly dependent on the physical and morphological characteristics of the substratum on which they adhere. The structure and dynamics of the substratum determines the number of species that can colonize it to the point of generating a high degree of specialization in epibiotic communities (Sebens 1991). Locating a suitable substratum on which to settle constitutes one of the most important behavioural stages in the life-history of all benthic sessile organisms. The availability of biological substrata such as macroalgae, seagrass and the external surface of many invertebrates, which are often periodically re. newed, can contribute to enlarging the choice of free available substrata on which to settle. Epibiosis is a common mechanism among many sessile marine organisms (Wahl 1989). Indeed, epibiosis allows the survival of many benthic species which have adapted their morphology and population dynamics to the characteristics of the biological substratum on which they settle. Most such epibiont species have short life cycles and high growth and reproductive rates (Jackson 1977, Seed 1985). This is also a pattern typical of organisms in the initial stages of an ecological succession.

The nature and availability of new substratum are some of the most important factors that regulate the settlement and survival of sessile organisms in benthic communities (Levin \& Paine 1974, Connell \& Keough 1985). Rocky substrata are usually scarce on the bottoms of the continental shelf and slope, and in these sandy and muddy habitats, epibiosis becomes a highly valuable process for the survival of sessile organisms. Decapod crustaceans constitute one of the few hard substrata available in such locations and although they may not usually show a high degree of colonization (Ross 1983), many decapods are hosts to sessile invertebrates (Stachowitsch 1977, Conover 1979). The small size of most crustaceans, together with the renewal of their carapaces due to moulting, 
are some of the factors that regulate the pattern of colonization by epibionts.

The portunid crab Bathynectes piperitus Manning \& Holthuis, 1981 is a common inhabitant of muddy bottoms on the upper slope (200 to $500 \mathrm{~m}$ ) of the Benguela upwelling region off Namibia (MelvilleSmith 1985, Abelló \& Macpherson 1989). The occurrence of lepadid barnacles and hydroid colonies on some individuals of $B$. piperitus has previously been noted by Manning \& Holthuis (1981) in their original description of $B$. piperitus. Abelló et al. (1990) described the incidence of epibionts on this crab as a function of the sex and size of the crab and inferred several biological and behavioural characteristics of the host crab from those data. The present work was undertaken to study the differential spatial distribution patterns of the different epibionts on $B$. piperitus as well as the population structure of 2 selected epibionts, a hydroid and a pedunculate cirriped, in an attempt to estimate the host carapace age structure from the epibionts present.

\section{MATERIAL AND METHODS}

Samples of Bathynectes piperitus were taken by trawling off southern Namibia (25 to $28^{\circ} \mathrm{S}$ ) on board the freezer trawler 'Sueve' between November 1987 and January 1988 at depths between 300 and $450 \mathrm{~m}$. The carapaces of crabs with epibionts were randomly selected, labelled and preserved in $5 \%$ formalin for later examination.

A total of 318 male crab carapaces with epibionts were examined for the determination of the differential distribution of each epibiont species on the host carapace and the population structure of the hydroid and the cirriped. The analysis was restricted to male crabs, since the sex-ratio in the study area is highly skewed to males and since they reach a larger body size (Abelló \& Macpherson 1989, 1992). In addition, the seasonal patterns of moulting in male portunid crabs appear to be more or less continuous throughout the year in most of those species studied.

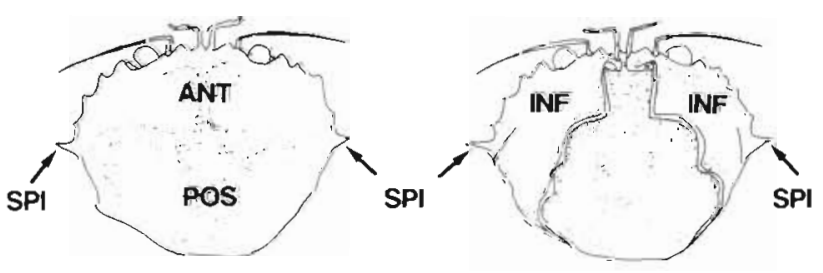

Fig. 1. Bathynectes piperitus. Carapace areas of crabs used in the present study. ANT: anterior; POS: posterior; INF: inferior; SPI: spines
Four carapace areas were studied: anterior dorsal part, posterior dorsal part, branchiostegites (or inferior part), and spines (Fig. 1). The division between the anterior and the posterior carapace dorsal parts was defined by the ridge between the fifth antero-lateral spines. The number of cirripeds and polychaetes, and the number of colonies of the hydroid and the bryozoan occurring in each area were noted for each crab studied.

Carapace length (CL, mm) was measured from the right frontal sinus to the posterior margin of the carapace. Capitulum length ( $\mathrm{mm}$ ) was taken as a size reference in the cirriped to study its size population structure. In the case of the hydroid, the total number of polyps in each colony and the number of gonothecae were recorded as indicators of size and maturity, respectively.

The Bhattacharya (1967) method was applied to the size frequency distributions of the cirriped to identify the number and mean sizes of the different normallydistributed cohorts in the polymodal distributions recorded.

\section{RESULTS}

Four species were identified as epibionts of Bathynectes piperitus: the hydroid Stegopoma plicatile (Sars, 1863), the polychaete Spirorbis patagonicus Caullery \& Mesnil, 1897, the pedunculate cirriped Poecilasma kaempferi Darwin, 1851, and the bryozoan Nolella annectens Harmer, 1915.

\section{Differential distribution of the epibionts on the host carapace}

Each epibiont species showed a clear tendency to occur on different specific areas of the carapace (Table 1). The hydroid Stegopoma plicatile and the cirriped Poecilasma kaempferi tended to be found (>75\%) on the dorsal surface of the carapace, with most hydroids positioned anteriorly, whilst most cirripeds were found posteriorly. Very few hydroids or cirripeds were found to occur on the branchiostegites, but they were almost the only species found on the antero-lateral spines of the carapace. The polychaete Spirorbis patagonicus was found most abundantly ( $>50 \%$ ) on the branchiostegites, and of the remainder, approximately $38 \%$ were found on the frontal part of the dorsal surface, with very few occurring on the posterior or on the spines. The bryozoan Nolella annectens tended to be found almost exclusively $(80 \%)$ on the branchiostegites, a few colonies occupying the posterior dorsal surface of the host carapace. 

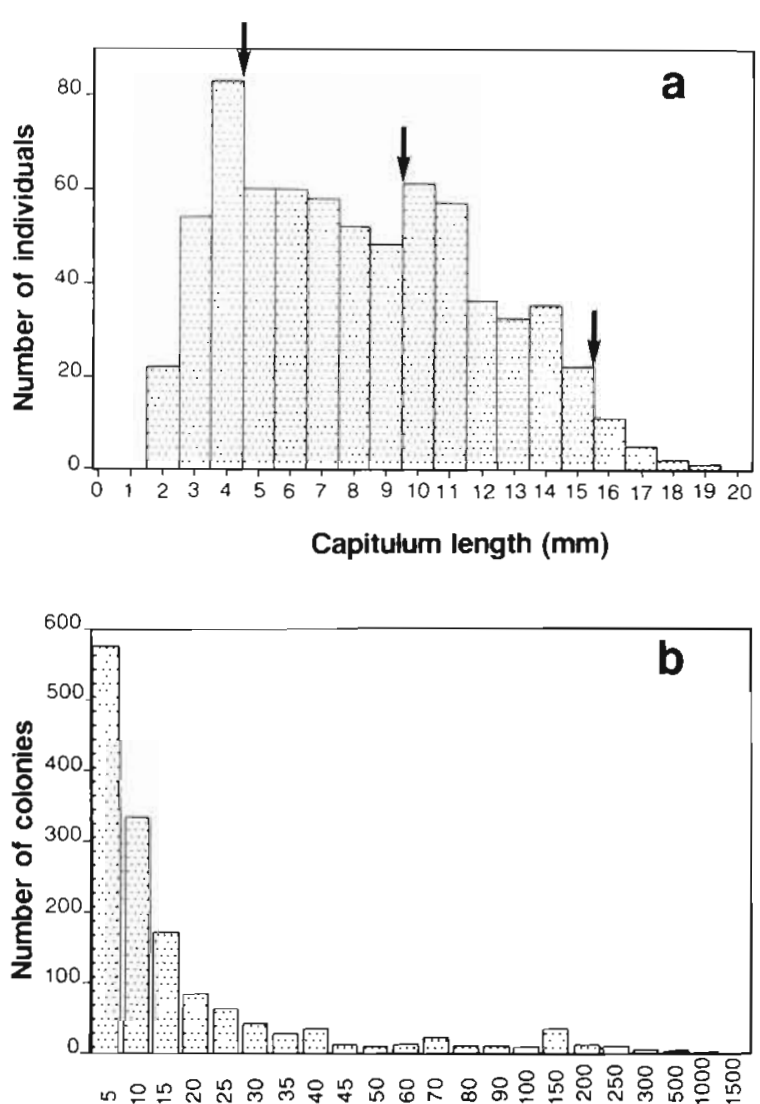

Colony size (number of polyps)

Fig. 2. (a) Poecilasma kaempferi. Overall size-frequency distribution (capitulum length) of pedunculate cirripeds with indication (arrows) of the mean sizes of the different cohorts identified by the Bhattacharya method. (b) Stegopoma plicatile. Colony size distribution of hydroids according to the number of polyps in each colony

\section{Population structure of Poecilasma kaempferi}

The size-frequency distribution of all the Poecilasma kaempferi examined was markedly polymodal (Fig. 2a). Three cohorts are distinguishable in the overall sizefrequency distribution with the first having a mean size of $4.5 \mathrm{~mm}$ capitulum length, the second $9.5 \mathrm{~mm}$, and the ca $15.5 \mathrm{~mm}$. Although a large number of recruits is evident compared with the number of larger-sized barnacles, the shape of the distribution is indicative of a
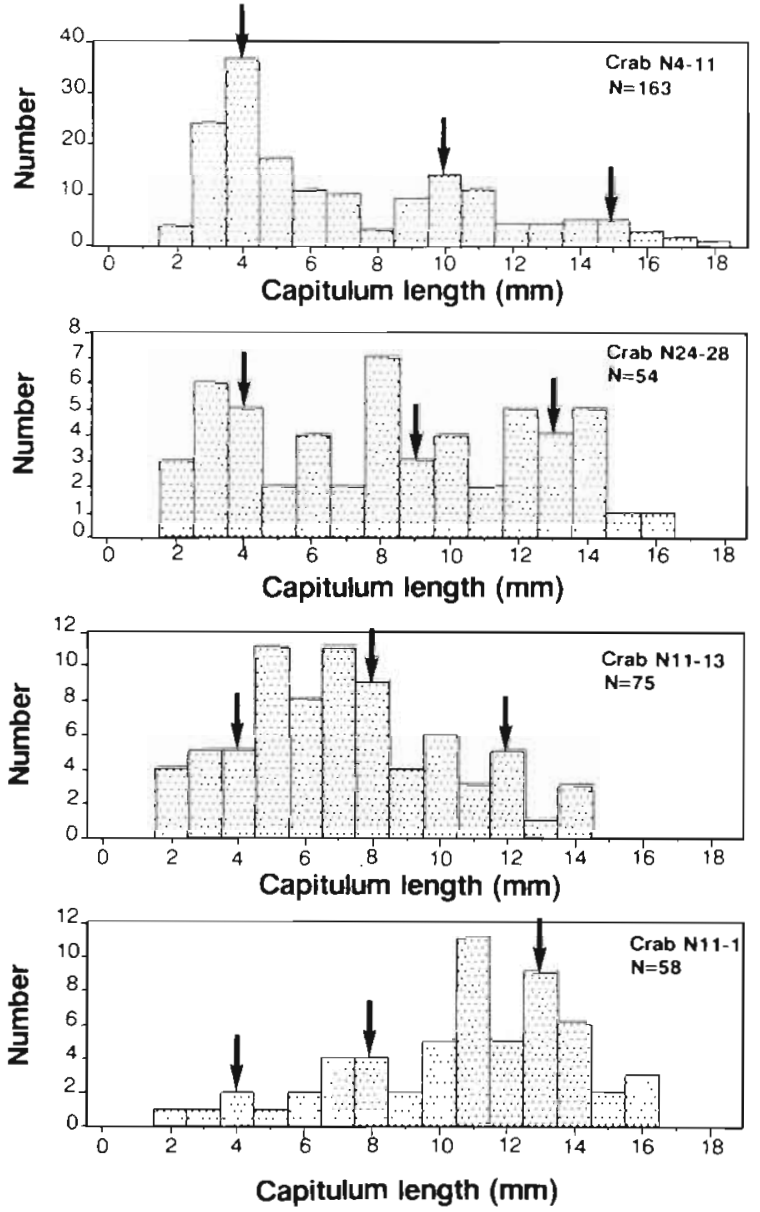

Fig. 3. Poecilasma kaempferi on Bathynectes piperitus. Size-frequency distributions of pedunculate cirripeds on 4 selected crabs with indication (arrows) of the mean sizes of the different cohorts identified by the Bhattacharya method

high survival once settled and of low recruitment. The occurrence of 3 distinct cohorts is readily evident in the size-frequency distributions of barnacles found on some individual crabs (Fig. 3).

\section{Population structure of Stegopoma plicatile}

The population structure of the hydroid (Fig. 2b) was markedly different from that of the lepadid barnacle. Fig. $2 b$ shows the frequency distribution of the

Table 1. Bathynectes piperitus. Percentages of the total number of each epibiont species found in each of the 4 crab carapace areas

\begin{tabular}{|lccccc|}
\hline Species & Anterior & Posterior & Inferior & Spines & n \\
\hline Stegopoma plicatile (hydroid) & 46.9 & 36.1 & 12.7 & 4.2 & 1485 \\
Spirorbis patagonicus (polychaete) & 38.1 & 8.0 & 53.1 & 0.8 & 1962 \\
Poecilasma kaempferi (cirripede) & 28.7 & 45.7 & 20.9 & 4.7 & 661 \\
Nolella annectens (bryozoan) & 3.4 & 16.1 & 80.3 & 0.2 & 615 \\
\hline
\end{tabular}



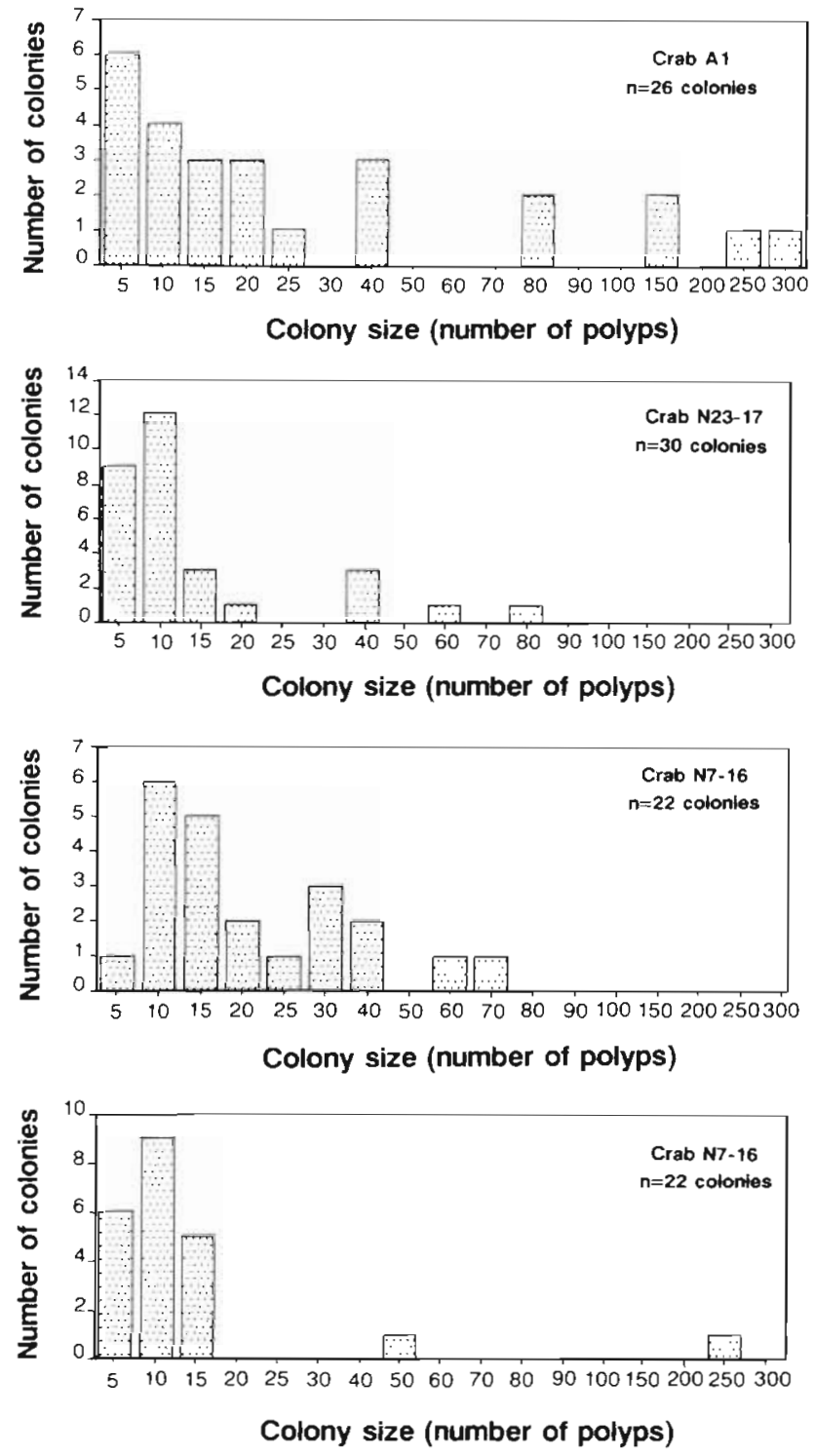

Fig. 4. Stegopoma plicatile on Bathynectes piperitus. Colony size distributions of hydroids on 4 selected crabs

hydroids by colony size class. Size classes have been used according to the number of polyps present in each colony. The observed distribution suggests a high level of recruitment which is then subject to a high mortality rate once settled. Differing from the cirriped, a dominance of recruit colonies in the overall hydroid population is distinguishable in Stegopoma plicatile (Figs. 2b \& 4).

Recruit colonies ( $\leq 10$ polyps) were present on crabs of all sizes studied (Fig, 5a), and no threshold of crab size is found where recruitment primarily occurs. Colonies in the sexual reproductive stage (with gonothecae) were also found on all the sizes of crabs studied (Fig. 5b). These 2 phenomena corroborate the
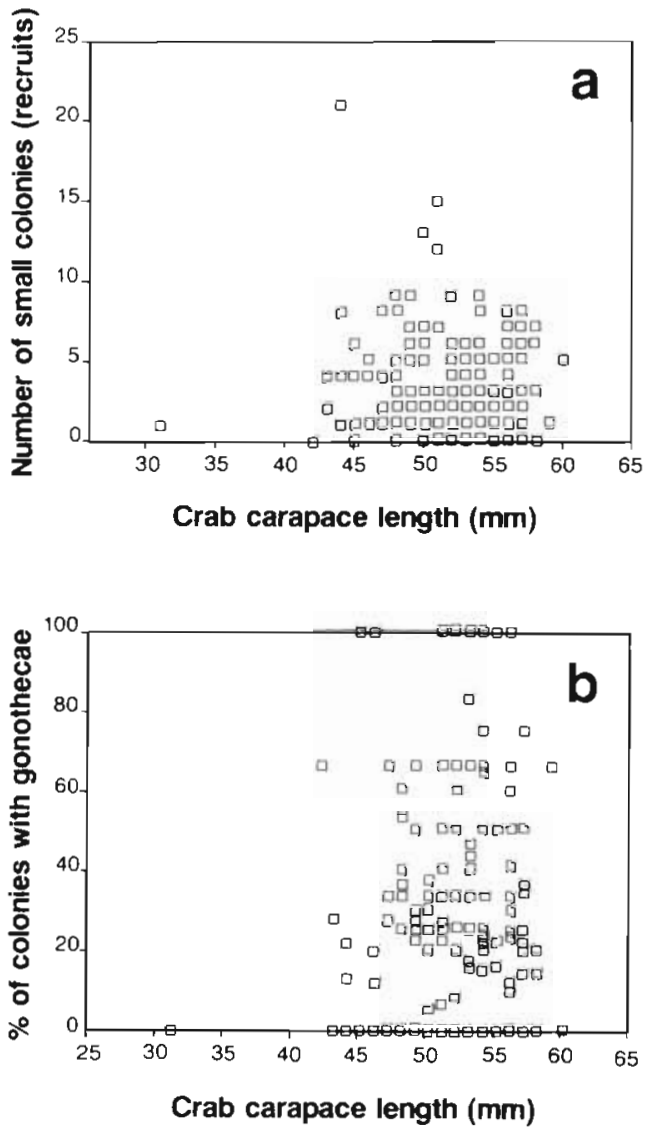

Fig. 5. Stegopoma plicatile on Bathynectes piperitus. (a) Number of recruits and (b) percentage of colonies with gonothecae, of $S$. plicatile in relation to crab size (carapace length)

fact that recruitment in this species is continuous and therefore there is an overlap between cohorts. All cohorts (all sizes of colonies) are able to reproduce. They can reproduce from a very small size: it should be noted that colonies of only 3 to 4 individuals may have gonothecae or produce asexual propagular stolons.

\section{DISCUSSION}

Decapod crustacean carapaces are frequently unsuitable as substrate for epibiont colonizers due to factors inherent in their biology and behaviour such as a short intermoult period, which is very variable depending on the species and the size of the individual, or the habit of burying into sand or mud (Ross 1983). This effectively reduces the amount of time that the substratum is available. In fact, for substrata which are being continuously perturbated or renewed the colonizer species are mainly short-lived, fugitive species; these can be considered as inferior competi- 
tors which would usually be excluded locally under pressure of interspecific competition (Paine \& Levin 1981, De Angelis \& Waterhouse 1987). Some seaweed species, like Ascophyllum nodosum, periodically shed their epidermis and therefore epibionts (FilionMykelbust \& Norton 1981, Russell \& Veltkamp 1984, Williams \& Seed 1992). This is the most similar mechanism to that found in crustaceans and effectively reduces the number and density of colonizing species. This general pattern of colonization contributes to explaining the fact that only 4 epibiont species have been found on Bathynectes piperitus. Moreover, the species found have a high degree of specificity in the area studied where, for example, Stegopoma plicatile has only been found on crustacean carapaces (Gili et al. 1989).

The spatial heterogeneity observed in the distribution of the epibionts is a generalized phenomenon in the epibiont communities of crustaceans (Lewis 1976 , Conover 1979, Cadée 1991). Resource partitioning may also have a role in this clear tendency for each epibiont species to occur in different areas of the host carapace. Many polychaete and bryozoan larvae are known to be negatively phototropic at the time of settlement, whilst many hydrozoan species are positively phototropic at that time (Thorson 1964). Thus, differences in larval behaviour may explain the distributions of polychaete and bryozoan occurring preferentially on the ventral surface of the carapace whilst the hydrozoan was found more commonly on the dorsal surface. Epibiotic spirorbids are known to infest preferentially the ventral surfaces of lobsters (KnightJones et al. 1975). Furthermore, hydrozoans are extremely sensitive to sedimentation (Boero 1984) to an extent where development can be impeded, which may further restrict their distribution on the host carapace. The main distribution areas for each epibiont species can therefore be assumed as their main settlement areas on the crab surface.

Suspension-feeding epibionts are favoured by the currents generated by the movement of the crustacean host which guarantee the arrival of food. Such encrusting suspension-feeding organisms, like the bryozoans and spirorbid polychaetes, are placed in habitats where water currents are constant, since they are passive filtering organisms (Jørgensen 1966). For the hydrozoan and cirriped species, their own morphology (erect organisms that grow vertically) constrains their position of settlement to free surfaces like the dorsal surface of the carapace (Jackson 1979). In such a position, these erect sessile species benefit from the mobility of the crab which increases water flow and so prey-capture ability (Heath 1976, Conover 1979).

The hydrozoan species tended to occur on the anterior dorsal surface of the carapace while the cirriped was found preferentially towards the posterior of the dorsal surface. Cirripeds (Heath 1976), hydrozoans (Wright 1973) and spirorbids (Knight-Jones et al. 1975) all tend to be gregarious species. Additionally, suspension-feeders like the hydrozoans monopolize the habitat where they grow, impeding or restricting the settlement of larvae of other species (Karlson 1978) as a side effect of space occupation. Some cnidarian suspension-feeders are known to feed on the larvae of neighbouring species, which reduces settlement and so competence (Sebens \& Koehl 1984). The effect that a given species may have on another will depend on which was the first to settle or on which is the most successful spatial competitor. The fact that the hydrozoan species is the most common epibiont on the dorsal surface of the crab and is very often found alone (Abelló et al. 1990) suggests that it may often be the first colonizing species and that it is a highly succesful competitor for space.

The colonies of the hydrozoan Stegopoma plicatile can reach a large size. The efficiency of the colonizing process of this species is demonstrated by the fact that in some cases several cohorts have been found on the same host. The colonizing success of $S$. plicatile is determined by its reproductive strategy. It has a continuous recruitment rate through the formation of asexual propagular stolons. These reproductive structures are common to many hydrozoans, especially among those with an epibiotic mode of life (Boero 1981, Coma et al. 1992). The use of asexual reproduction by modular organisms, such as the hydrozoans, allows the maintenance of populations in a restricted zone by reducing the distance of propagation with a subsequent decrease in the risk of loss to unsuitable substrates (Jackson 1986). Moreover, the gregarious character of many benthic decapod crustacean populations facilitates the dispersion of the epibionts within the same crab population (Conover 1979). Through both types of reproduction, asexual and sexual (gonothecae which produce epibenthic larvae), the species is effectively able to recruit continuously, as demonstrated by the high presence of recruit colonies and of colonies with gonothecae in all carapace sizes of the host crab. This reproductive strategy allows them to successfully colonise the substratum irrespective of the dynamics of the substratum, in a similar way to epibiotic hydrozoans on algae whose fronds are continuously renewed (Coma et al. 1992) or in bryozoans (Seed 1985, Cancino 1986).

The occurrence of different and distinguishable cohorts in the size distribution of the cirriped Poecilasma kaempferi strongly suggests that seasonality in reproduction takes place in this deep-water species, as was also indicated for the same cirriped by Williams \& Moyse (1988) in the North Atlantic, 
based on the absence of embryos in the samples they examined.

One of the starting hypotheses in this work made reference to the possibility of ageing the hosts carapace by estimating the age of the epibionts. This is not an easy task since it was not possible to obtain an exact measure of the residence time of the epibionts studied. However, and as a way of approach to this problem, this may be possible if the growth rates of the epibiont species or of similar species is known through bibliographic references. The colonies of Stegopoma plicatile reach a size (height) of $3 \mathrm{~cm}$ when they have 20 to 30 polyps, $7 \mathrm{~cm}$ with 70 to 80 polyps, $9 \mathrm{~cm}$ with ca 150 polyps, and $12 \mathrm{~cm}$ with more than 500 polyps. A growth rate of 2 to $3 \mathrm{~cm} \mathrm{mo}^{-1}$ has been reported for Nemertesia antennina (Hughes 1977), a hydrozoan which inhabits the continental shelf on sandy and muddy bottoms. Even though its morphology is not very similar to that of $S$. plicatile, it is the only species of the group with a known 'in situ' growth rate and which reaches similar dimensions and grows in a similar habitat as that of $S$. plicatile. From these data we can assume that crab carapaces with colonies of 100 to 200 polyps are at least 3 mo old, whereas those with the largest colonies found, of ca 1000 polyps, may be at least 6 mo old. However before settlement can occur, the host surface must first be covered by a bacterial film, a process estimated to take a minimum of 1 mo from host ecdysis. From this, we can predict that at least 1 or 2 more months should be added to the calculated substratum residence time from the known epibionts.

The cirriped Poecilasma kaempferi has a high growth rate and can attain a size of $10 \mathrm{~mm}$ capitulum length in only 6 mo and has been shown to grow up to $17 \mathrm{~mm}$ in $8 \mathrm{mo}$ in the North Atlantic deep-sea (Lampitt 1990). Accordingly, crab carapaces with barnacles measuring more than 10 mum capitulum length are again estimated to be at least 6 mo old. A high growth rate would be of highly adaptive significance to epibiont species since sexual maturity must be achieved before the host moults.

The population structure of the epibiont species and community must reflect not the age of the host crab, but the age of the crab's carapace. Few attempts have been made to age decapod carapaces (Le Foll et al 1987, Conan et al. 1990, Latrouite et al. 1990) and the methodologies used are often complex, expensive and do not allow the analysis of large numbers of samples. The relationships between the host carapace age and the population characteristics of the epibionts would be increasingly known if a cheap and reliable method were available to analyse large samples.

In conclusion, because the process of colonization of the carapaces of Bathynectes piperitus follows a model of succession where the moulting periods should mark the perturbation that would reinitiate the succession, the age of the epibionts can be an approximate measure of the intermoult period of the crustacean.

Acknowledgements. We thank Prof. E. Naylor and Dr R. Seed (University of Wales, UK) and $\mathrm{Dr}$ C.G. Warman (Odense University, Denmark) for their comments and suggestions We are very grateful to $\mathrm{L}$. Hernandez and $T$. Hornos for their assistance.

\section{LITERATURE CITED}

Abelló, P., Macpherson, E. (1989). Distribution of Bathynectes piperitus (Brachyura: Portunidae) in the Benguela upwelling region and its relationship with some environmental parameters. J. Crust. Biol. 9: 373-380

Abelló, P., Macpherson, E. (1992). Epibiosis and rhizocephalan infestation patterns in relation to the reproductive biology of Lithodes ferox (Filhol, 1885) (Anomura Lithodidae). J. Crust. Biol. 12: 561-570

Abelló, P., Villanueva, R., Gili, J. M. (1990). Epibiosis in deepsea crab populations as indicator of biological and behavjoural characteristics of the host. J. mar. biol. Ass. U.K. 70 $687-695$

Bhattacharya, C. G. (1967). A simple method of resolution of a distribution into gaussian components. Biometrics 23 $115-135$

Boero, F. (1981). Systematics and ecology of the hydroid population of two Posidonia oceanica meadows. P.S.Z.N. I Mar. Ecol. 2: 181-197

Boero, F. (1984). The ecology of marine hydroids and effects of environmental factors: a review. P.S.Z.N. I: Mar. Ecol 5: $93-118$

Cadée, G. C. (1991). Carapaces of the shore crab Carcinus maenas as a substrate for encrusting organisms. Bull. Soc Sci. Nat. Ouest Fr. Mém. HS1: 71-79

Cancino, J. M. (1986). Marine macroalgae as a substratum for sessile invertebrates: a study of Celleporella hyalina (Bryozoa) on fronds of Laminaria saccharina (Phaeophyta). Monogr. Biol. 4: 279-308

Coma, R., Llobet, I., Zabala, M., Gili, J. M., Hughes, R. G. (1992). The population dynamics of Halecium petrosum and Halecium pusillum (Hydrozoa, Cnidaria), epiphytes of Halimeda tuna in the northwestern Mediterranean. Scientia Mar. 56: 161-169

Conan, G. Y., Laubier, L., Brichet, E., Reyss, J. L., Laloue, C. (1990). Dating of snow crab carapaces using radioelements. ICES 1990 Shellfish Symp. 163: 136

Connell, J.H., Keough, M.J. (1985). Disturbance and patch dynamics of subtidal marine animals on hard substrata. In: Pickett, S. T. A., White, P. S. (eds.) The ecology of natural disturbance and patch dynamics. Academic Press, San Diego, p. $125-151$

Conover, M. R. (1979). Effect of gastropod shell characteristics and hermit crabs on shell epifauna. J. exp. mar. Biol. Ecol. 40: $81-94$

De Angelis, P. L., Waterhouse, J. C. (1987). Equilibrium and nonequilibrium concepts in ecological models. Ecol. Monogr. 57: 1-21

Filion-Mykelbust, C., Norton, I A. (1981). Epidermis shedding in the brown seaweed Ascophyllum nodosum (L.) Le Jolis and its ecological significance. Mar. Biol. Lett. 2: $45-51$ 
Gili, J. M., Wervoort, W. Pagès, F. (1989). Hydroids from the West African coast: Guinea Bissau, Namibia and South Africa. Scientia Mar. 53: 67-112

Heath, D. J. (1976). The distribution and orientation of epizoic barnacles on crabs. Zool. J. Linnean Soc. 59: 59-67

Hughes, R. G. (1977). Aspects of the biology and life-history of Nemertesia antennina (L.) (Hydrozoa: Plumularidae). J. mar. biol. Ass. U.K. 57: 641-657

Jackson, J. B. C. (1977). Competition on marine hard substrata the adaptive significance of solitary and colonial strategies. Am. Nat. 111: 743-767

Jackson, J. B. C. (1979). Morphological strategies of sessile animals. In: Larwood, G. P., Rosen, D. R. (eds.) Biology and systematics of colonial organisms. Academic Press, New York, p. 499-555

Jackson, J. B. C. (1986). Modes of dispersal of clonal benthic invertebrates: consequences for species' distributions and genetic structure of local populations. Bull mar. Sci. 39: $588-606$

Jørgensen, C. B. (1966). Biology of suspension feeding. Pergamon Press, Oxford

Karlson, R. (1978). Predation and space utilization patterns in a marine epifaunal community. J. exp. mar. Biol. Ecol. 31: $225-239$

Knight-Jones, E. W., Knight-Jones, P., Al-Ogily, S. M. (1975). Ecological isolation in the spirorbidae. In: Barnes, H. (ed.) Proc. 9th Eur. mar. Biol. Symp. Aberdeen University Press, Aberdeen, p. 539-561

Lampitt, R. S. (1990). Directly measured rapid growth of a deep-sea barnacle. Nature 345: 805-807

Latrouite, D., Reyss, J. L., Noël, P., Brichet, E. (1990). Growth study of crustaceans by measurement of carapace ${ }^{228}$ thorium and ${ }^{228}$ radium radioactivity. ICES 1990 Shellfish Symp. 133: 106

Le Foll, D., Brichet, E., Reyss, J. L. (1987). Détermination de l'âge d'araignées de mer Maia squinado par mesure des radio-isotopes $\mathrm{Th}^{228}$ et $\mathrm{Ra}^{228}$ de la carapace. Comm. Meet. int. Coun. Explor. Sea C.M.-[CES/K: 43

Levin, S. A., Paine, R. T (1974). Disturbance patch formation and community structure. Proc. natl Acad. Sci. U.S.A. 71. $2744-2747$

Lewis, E. G. (1976). Epizoites associated with Bathynectes superbus (Decapoda: Portunidae). Fish. Bull. U.S. 74: $225-227$

Manning, R. B., Holthuis, L. B. (1981). West African brachyuran crabs (Crustacea: Decapoda). Smithson. Contr. Zool. 306: $1-379$

Melville-Smith, R. (1985). Density distribution by depth of Geryon maritae on the northern crab grounds of south

This article was submitted to the editor west Africa/Namibia determined by photography in 1983, with notes on the portunid crab Bathynectes piperitus S. Afr. J. mar. Sci. 3: 55-62

Paine, R. T., Levin, S. A. (1981). Intertidal landscapes disturbance and the dynamics of pattern. Ecol. Monogr 51: $145-178$

Ross, D. M. (1983). Symbiotic relations. In: Vernberg, S. J., Vernberg, W. B. (eds.) The biology of Crustacea, Vol. 7 , Behavior and ecology. Academic Press, New York, p. $163-212$

Russell, G., Veltkamp, C. J. (1984). Epiphyte survival on skin shedding macrophytes. Mar. Ecol. Prog. Ser. 18: $149-153$

Sebens, K.P. (1991). Habitat structure and community dynamics in marine benthic systems. In: Bell, S. S., McCoy, E. D., Mushinsky, H. R. (eds.) Habitat structure. The physical arrangement of objects in space. Chapman \& Hall, London, p. 211-234

Sebens, K. P., Koehl, M. A. R. (1984). Predation on zooplankton by the benthic anthozoans Alcyonium siderium (Alcyonacea) and Metridium senile (Actiniaria) in the New England subtidal. Mar. Biol. 81: 255-271

Seed, R. (1985). Ecology patterns in the epifaunal communities of coastal macroalgae. In: Moore, P.G., Seed, R. (eds.) The ecology of rocky coasts. Hodder and Stoughton, London, p. 22-35

Stachowitsch, M. (1977). The hermit crab microbiocoenosis - the role of mobile secondary hard bottom elements in a north Adriatic benthic community. In: Keegan, B. F., $\mathrm{O}^{\prime}$ Ceidigh, P., Boaden, P. J. S. (eds.) Biology of benthic organisms. Pergamon Press, London, p. 549-558

Thorson, G. (1964). Light as an ecological factor in the dispersal and settlement of larvae of marine bottom invertebrates. Ophelia 1: 67-208

Wahl, M. (1989). Marine epibiosis. I. Fouling and antifouling: some basic aspects. Mar. Ecol. Prog. Ser. 58: 175-189

Williams, G. A., Seed, R. (1992). Interactions between macrofaunal epiphytes and their host algae. In: John, D. M., Hawkins, S. J., Price, J. H. (eds.) Animal interactions in the marine benthos. Clarendon Press, Oxford, p. $189-211$

Williams, R, Moyse, J. (1988). Occurrence, distribution, and orientation of Poecilasma kaempteri Darwin (Cirripedia: Pedunculata) epizoic on Neolithodes grimaldi MilneEdwards and Bouvier (Decapoda: Anomura) in the northeast Atlantic. J. Crust. Biol. 8: 177-186

Wright, H. O. (1973). Effect of commensal hydroids on hermit crab competition in the littoral zone of Texas. Nature 241: $139-140$

Manuscript first received: January 25, 1993

Revised version accepted: May 24, 1993 